\title{
Feeding habits and morphometry of Iheringichthys labrosus (Lütken, 1874) in the Uruguay River (Uruguay)
}

\author{
Malvina Masdeuㄹ, Franco Teixeira-de Mello ${ }^{1,2}$, Marcelo Loureiro ${ }^{3,4}$ and Matias Arim ${ }^{3,5}$
}

Body size and diet of organisms are fundamental attributes which determine their ecology and natural history. Iheringichthys labrosus is one of the most common fish species of the Uruguay River. However, its natural history is poorly known and there is little information about its diet and interactions with other species. This paper describes the feeding habits of this species, relating feeding patterns to the size classes and morphometry of individuals and to the temporal variations. Fishes were captured in May and November of 2006 in three zones of the lower Uruguay River. A total of 101 stomach contents was analyzed (standard length: $60-224 \mathrm{~mm}$ ). The species exhibited a broad feeding spectrum with most items belonging to the benthic community. We found significant diet differences between size classes and studied months. However, we have not found a close relationship between changes in morphometric variables and diet shifts between size classes.

O tamanho do corpo e a dieta são atributos fundamentais que determinam a ecologia e a história de vida dos organismos. Iheringichthys labrosus é uma das espécies mais comuns do rio Uruguai, entretanto, sua história natural é pouco conhecida e particularmente existe pouca informação sobre sua dieta e interações com outras espécies. Este artigo descreve os hábitos alimentares de I. labrosus, associando os padrões de alimentação com as classes de tamanho, à morfometria dos indivíduos e às variações temporais. Um total de 101 estômagos foi analisado (comprimento padrão: 60-224 mm). Os peixes foram capturados durante Maio e Novembro de 2006 em três áreas da porção inferior do rio Uruguai. Iheringichthys labrosus exibiu um amplo espectro alimentar, com a maioria dos componentes da dieta pertencentes à comunidade bentônica. Foram encontradas diferenças significativas na dieta em relação às classes de tamanho dos indivíduos e aos meses de estudo. No entanto, não foram encontradas relações estreitas entre as variáveis morfométricas analisadas e variações na dieta entre as classes de tamanho.

Key words: Diet, Freshwater, Natural history, Pimelodidae, Siluriformes.

\section{Introduction}

Studies on feeding habits are essential to understand species biology since they contribute to the comprehension of population trophic interactions (Deus \& Petrere-Junior, 2003). Moreover, these studies are essential to evaluate the importance of organisms within the ecosystem (Pouilly et al., 2006). Diet is usually considered as an attribute of the species, neglecting the large intraspecific diet variations related to differences in morphology among individuals (Raffaelli, 2007) and from resources availability among populations (Dill, 1983).
Intraspecific variations in feeding habits and particularly ontogenetic changes in diet are notable widespread among fish populations (Wootton, 1992; Lowe et al., 1996; Rowe \& Chisnall, 1996). Feeding abilities frequently change during fish development due to changes in morphometric traits (e.g. eye diameter, head length, body weight). This may determine physical constrains on prey size and food selectivity (Wainwraigth \& Richard, 1995; Arim et al., 2010). Particularly, change in mouth size and oral anatomy is considered one important determinant of intraspecific partitioning of food (Ward-Campbell \& Beamish, 2005). The idea that fish

\footnotetext{
${ }^{1}$ Grupo de Ecología y Rehabilitación de Sistemas Acuáticos, Departamento de Ecología y Evolución, CURE-Facultad de Ciencias, Universidad de la República, CP 20000 Maldonado, Uruguay.malvinish@hotmail.com (MM), frantei@fcien.edu.uy (FTM)

${ }^{2}$ Asociación Investigación y Desarrollo I+D, Iguá 4225, CP 11400 Montevideo, Uruguay.

${ }^{3}$ Sección Vertebrados, Facultad de Ciencias, Iguá 4225, CP 11400 Montevideo, Uruguay.

${ }^{4}$ Departamento de Ictiología, Museo Nacional de Historia Natural y Antropología, Juan Carlos Gómez 582, CP 11400 Montevideo, Uruguay.

${ }^{5}$ Center for Advanced Studies in Ecology \& Biodiversity (CASEB) and Departamento de Ecología, Facultad de Ciencias Biológicas, Pontificia Universidad Católica de Chile, CP 6513677 Santiago, Chile.
} 
morphology determines feeding abilities is widely accepted, however, the effect of morphology on feeding performance has been poorly studied (Kramer \& Bryant, 1995a; Hjelm et al., 2000; Teixeira-de Mello et al., 2006). In this sense, the analysis of the feeding ecology of fish species requires a detailed consideration of ontogenetic changes in diet and the related variation in those morphological attributes associated with individual ability to prey consumption. In addition, the analysis of feeding behaviour between different time periods and environments is essential to understand species potential to adjust its diet to variations in resources availability and internal demands.

Iheringichthys labrosus (Lütken, 1874; Siluriformes, Pimelodidae) is a South American non migratory freshwater fish that is abundant in numerous reservoirs (Burges, 1989) and rivers (Abes et al., 2001; Teixeira-de Mello et al., 2008). The maximum total length reported for this species is $33.4 \mathrm{~cm}$ (Fagundes et al., 2008). Iheringichthys labrosus shows no parental care behaviour and reproduces along the year, with multiple spawning reproductive peaks synchronized with rainy season (Santos et al., 2006). This species exhibits a sub-terminal mouth, with dentigerous plates (Fugi et al., 2001), thick lips and free superior margin (Abes et al., 2001). It has a wide space between gill rakers, a sacciform stomach and a short intestine (Fugi et al., 2001). Particularly, this species is one of the most abundant in Paraná River basin which counts with several local studies of its feeding habits (e.g. Fugi et al., 2001; Abes et al., 2001; Peretti \& Andrian, 2004).

In spite of I. labrosus is also a very abundant species in Uruguay River basin (Bertoletti et al., 1989; Teixeira-de Mello et al., 2008) there is scarce information about its biology. Particularly, only one study about the diet of this species was conducted in the Ibicuí River, one of the most important tributaries of Uruguay River (Fagundes et al., 2008). Previous studies have defined this species as benthivorous. However, this general classification does not account for inter-individual variations and was performed in different environmental conditions than those observed in Uruguay.

The limited available information about the biology of $I$. labrosus and the main role that this abundant species could have in the ecosystem highlights the importance to advance on the knowledge of its diet. This paper describes the feeding habits of I. labrosus at the Uruguay River and analyzes dietary changes between size classes and times of the year in relation to individual morphology.

\section{Material and Methods}

The study area is located in the lower section of Uruguay River, between Nuevo Berlín and Las Cañas (Río Negro province, Uruguay). In the last years average discharge and depth of the studied section are: $6231 \mathrm{~m}^{3} \mathrm{~s}^{-1}$ and $2.15 \mathrm{~m}$, respectively (DINAMA, 2005). Fishes were collected during May and November of 2006 in three sample sites. Site I is located in Nuevo Berlín (NB) (32 $58^{\prime} 52^{\prime}$ 'S 58 $54^{\circ}$ '06" W), site II (Y) $\left(33^{\circ} 06^{\prime} 35^{\prime \prime} \mathrm{S} 58^{\circ} 16^{\prime} 39^{\prime \prime} \mathrm{W}\right)$ is located $27 \mathrm{~km}$ downstream of site
I, and site III (LC) (3309'48”'S 58 21'43”'W) $15 \mathrm{~km}$ downstream of site II (Fig. 1). Environmental characteristics of each sample site are shown in Table 1. The selected sites are monitoring points commissioned by Botnia (nowadays part of UPM) for the installation of a pulp mill that started to operate in 2007. Therefore, the present information can be considered as baseline for future investigations of environmental assessment.

Specimens of I. labrosus analyzed were collected with eigth multimesh nets of $30 \mathrm{~m}$ each (meshes: 5.0, 6.25, 8.0, 10.0, 12.5, 15.5, 19.5, 24, 29, 35, 43 and $55 \mathrm{~mm}$ knot to knot, each mesh: 2.5 $\mathrm{m})$, that were simultaneously operated. Gillnets were placed from afternoon to next morning. Thirty species were collected during May, while 42 were obtained in November. Iheringichthys labrosus abundance represents $42.4 \%$ and $51.1 \%$ of the total abundance of all species, respectively for each month.Collected individuals were preserved at $0^{\circ} \mathrm{C}$ until laboratory analysis. Following this, some representative specimens were deposited in the Vertebrate Collection of Facultad de Ciencias, Montevideo, Uruguay (Nuevo Berlín: ZVC - P 9025, Fray Bentos: ZVC-P 9026 and Las Cañas: ZVC-P 9027).

\section{Stomach content and data analysis}

In order to achieve an acceptable confidence in items detection, we estimated the number of stomachs to be sampled to achieve at least a 0.9 probability in order to detect those items with an occurrence $\geq 0.1$. Following these criterions we used the following equation: $N=\log (1-a) / \log (1-P)$, being $N$ the number of stomachs required to achieve a probability $a$ of prey detection (0.9), when its occurrence in diet is $P(0.1)$ (e.g. Arim \& Naya, 2003). With this approach we estimated a minimum number of 22 stomachs for each size class. Individuals were eviscerated in the laboratory and their stomach contents were inspected under stereomicroscope and dissecting microscope. Each alimentary item was counted and classified according to their taxonomic group.

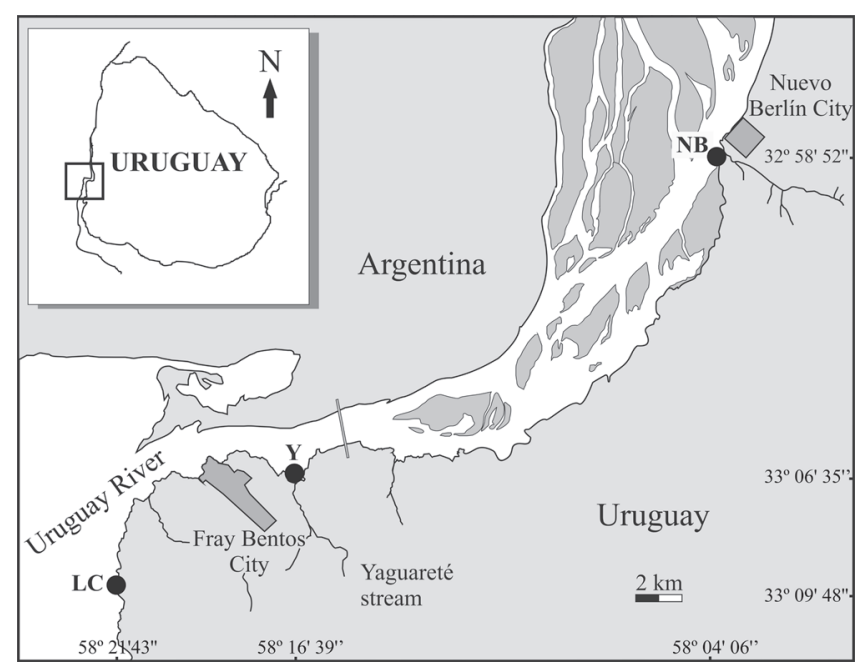

Fig. 1. Map of the study area. Samples sites are located on the Uruguay River: LC: Las Cañas, NB: Nuevo Berlín and Y: Yaguareté. 
Table 1. Environmental characteristics of Uruguay River in Nuevo Berlín (NB), Yaguareté (Y) and Las Cañas (LC): dissolved oxygen $\left(\mathrm{O}_{2}\right)$, turbidity, conductivity, $\mathrm{pH}$, and temperature during May $(\mathrm{M})$ and November $(\mathrm{N})$.

\begin{tabular}{lcccccccccc}
\hline Sites & \multicolumn{2}{c}{$\begin{array}{c}\mathrm{O}_{2} \\
\left(\mathrm{mgL}^{-1}\right)\end{array}$} & \multicolumn{2}{c}{$\begin{array}{c}\text { Turbidity } \\
(\mathrm{NTU})\end{array}$} & $\mathrm{pH}$ & \multicolumn{2}{c}{$\begin{array}{c}\text { Conductivity } \\
\left(\mu \mathrm{Scm}^{-1}\right)\end{array}$} & \multicolumn{2}{c}{$\begin{array}{c}\text { Temperature } \\
\left({ }^{\circ} \mathrm{C}\right)\end{array}$} \\
\hline & $\mathrm{M}$ & $\mathrm{N}$ & $\mathrm{M}$ & $\mathrm{N}$ & $\mathrm{M}$ & $\mathrm{N}$ & $\mathrm{M}$ & $\mathrm{N}$ & $\mathrm{M}$ & $\mathrm{N}$ \\
$\mathrm{NB}$ & 9.1 & 8.0 & 27 & 29 & 7.4 & 7.1 & 68 & 49 & 15.5 & 22.8 \\
$\mathrm{Y}$ & 9.0 & 7.8 & 22 & 29 & 7.7 & 7.1 & 71 & 59 & 16.0 & 22.8 \\
$\mathrm{LC}$ & 0.0 & 8.0 & 14 & 28 & 7.2 & 7.3 & 74 & 53 & 15.2 & 23.7 \\
\hline
\end{tabular}

Diet analysis was performed considering two size classes. These classes were defined according to the maturity of the gonads. The size class 1 ranged from 60 to $119 \mathrm{~mm}$ of standard length and corresponds to individuals whose macroscopic gonad analysis does not allow to determine their sex. The size class 2 ranged from 120 to $224 \mathrm{~mm}$ of standard length and included individuals whose macroscopic gonad analysis allows determining their sexes. To evaluate the feeding strategy of both size classes of fishes and the importance of each prey item in diet, the graphic representation of Amundsen et al. (1996) was used. In this diagram the prey specific abundance $\left(\mathrm{P}_{\mathrm{i}}\right.$ : percentage of prey $\mathrm{i}$ comprises all prey items in only those individuals in which i prey occurs; $\mathrm{Pi}=\left(\Sigma \mathrm{S}_{\mathrm{i}} / \Sigma \mathrm{S}_{\mathrm{t}}\right)$ $\mathrm{x} 100$, were $\mathrm{Pi}$ is prey specific abundance, $\mathrm{S}_{\mathrm{i}}$ the abundance of prey $i$ in stomachs and $S_{t}$ the total stomach content in only those individuals with prey $i$ in the stomach) is plotted against the frequency of occurrence $\left(\mathrm{F}_{\mathrm{i}}\right.$ : number of stomachs in which prey $i$ occurs, expressed as a frequency of the total number of stomachs with content). In addition, the percentage abundance of items $\left(\% \mathrm{~A}_{\mathrm{i}}=\left(\Sigma \mathrm{S}_{\mathrm{i}} / \Sigma \mathrm{S}_{\mathrm{t}}\right) \times 100\right.$, was $\% \mathrm{~A}_{\mathrm{i}}$ is the percentage abundance of prey $i, S_{i}$ the abundance of prey $i$ in stomachs and $\mathrm{S}_{\mathrm{t}}$ the total stomach contents of all individuals) is also presented (Hyslop, 1980).

\section{Morphometric measures}

Following Kramer \& Bryant (1995b) and Lima-Junior \& Goiten (2003), six morphometric variables were measured to the nearest $1 \mathrm{~mm}$ and $0.01 \mathrm{~g}$ in at least 20 individuals of the total collection: standard length, intestine length, eye diameter, mouth width, head length, and body weight (Table 2). Linear regressions were performed between intestine length, body weight and head length as dependent variables and standard length as independent variable. In addition, eye diameter and mouth width were associated with head length. Regressions were evaluated with ANOVA tests and relationships were considered statistically significant when $P<0.05$. To check if morphometric variables growth was statistically different from isometric growth, a $t$-test (H0: $b=1$ or $\mathrm{H} 0: b=3$ for lengthlength and length-weight relationships, respectively), with $\alpha$ $=0.05$ was performed.

\section{Diet variations between size classes}

The possible intraspecific variations in diet of fishes were inspected considering two size classes defined as described
Table 2. Morphometric variables measured in Iheringichthys labrosus.

\begin{tabular}{ll}
\hline Morphometric variables & Description \\
\hline Standard length & $\begin{array}{l}\text { Linear distance between the anterior part of } \\
\text { the head and the last vertebra of the spinal } \\
\text { column. } \\
\text { Measurement from cardia to anus. }\end{array}$ \\
$\begin{array}{l}\text { Intestine length } \\
\text { Eye diameter }\end{array}$ & $\begin{array}{l}\text { Horizontal diameter of the orbicular cavity. } \\
\text { Mouth width }\end{array}$ \\
mead length & $\begin{array}{l}\text { Linear distance from the most anterior margin } \\
\text { of the head to the most posterior margin of the } \\
\text { opercular membrane. }\end{array}$ \\
& Total wet weight. \\
\hline
\end{tabular}

above. Correspondence analysis (CA) was used to describe the main sources of diet variation. Some prey items were excluded from the analysis because of their low occurrence $\left(\mathrm{F}_{\mathrm{i}} \leq 0.25\right)$. The existence of significant differences between diet of class 1 and 2 fishes was evaluated with a Pearson Chi square test (Sokal \& Roholf, 1969). In this test the $\chi^{2}$ is calculated as $\chi^{2}=\Sigma(\mathrm{O}-\mathrm{E})^{2} / \mathrm{E}$, being $\mathrm{O}$ the observed abundances of prey items in diet and $\mathrm{E}$ the expected abundance when there is no association between diet and size class.

\section{Temporal diet variations}

Chi square test (equation detailed above) was used to determine temporal statistical differences in diet, separated by fishes of each size class. Correspondence analysis (CA) was used to describe the main sources of diet variation between months (May and November). This analysis include only those preys with an occurrence higher than 0.4 in at least one of the studied months.

\section{Results}

\section{Diet analysis}

Hundred and one stomach contents were analyzed (standard length: 60-224 mm), 53 from May sampling (11 of them were empty) and 48 from November sampling (4 stomachs were empty). Diet components were classified into 17 prey groups; 13 were identified at a taxonomic level and the remaining were classified as: arthropod remains, vegetal remains, sediment/debris and others (casual items: scales, seeds and unidentified items) (Table 3).

Amundsen diagrams support the generalist categorization of I. labrosus feeding strategy, independently of size classes of individuals. In May, this diagram showed that Copepoda was the dominant item (frequency and abundance) in diet of individuals of size class 1. However, Ostracoda, Diptera, Bivalvia, Nematoda and Gastropoda were the most frequent items, but with low values for $\mathrm{P}_{i}$ (Fig. 2a). In November, the diagram showed that Copepoda was the most abundant item, but with lower frequency than in May. Diptera was the most frequent item, followed by Nematoda, Bivalvia and Ostracoda (Fig. 2c).

Amundsen diagram for individuals of size class 2 during 
Table 3. Descriptive estimations of Iheringichthys labrosus diet: frequency of occurrence (F) and percent abundance (\% A) of prey items. Estimations were made from captures of May and November to individuals for each size class (1 and 2), from Uruguay River (Uruguay). *Immature biv.: immature bivalvia; item separately from Bivalvia group because of it high abundance, small size and low frequency of occurrence.

\begin{tabular}{|c|c|c|c|c|c|c|c|c|}
\hline \multirow[b]{3}{*}{ Food items } & \multicolumn{4}{|c|}{ May } & \multicolumn{4}{|c|}{ November } \\
\hline & \multicolumn{2}{|c|}{$\begin{array}{l}\text { Range 1: } \\
60-90 \mathrm{~mm} \\
(\mathrm{~N}: 22) \\
\end{array}$} & \multicolumn{2}{|c|}{$\begin{array}{c}\text { Range 2: } \\
120-75 \mathrm{~mm} \\
(\mathrm{~N}: 20)\end{array}$} & \multicolumn{2}{|c|}{$\begin{array}{c}\text { Range 1: } \\
64-119 \mathrm{~mm} \\
(\mathrm{~N}: 21)\end{array}$} & \multicolumn{2}{|c|}{$\begin{array}{c}\text { Range 2: } \\
124-224 \mathrm{~mm} \\
(\mathrm{~N}: 23)\end{array}$} \\
\hline & $\mathrm{F}$ & $\% \mathrm{~A}$ & $\mathrm{~F}$ & $\% \mathrm{~A}$ & $\mathrm{~F}$ & $\% \mathrm{~A}$ & $\mathrm{~F}$ & $\% \mathrm{~A}$ \\
\hline Diptera & 0.86 & 8.55 & 1.00 & 44.67 & 0.90 & 10.18 & 0.70 & 76.66 \\
\hline Bivalvia & 0.86 & 7.99 & 0.95 & 27.36 & 0.60 & 5.86 & 0.50 & 0.93 \\
\hline Immature biv.* & 0.05 & 3.27 & - & - & - & - & - & - \\
\hline Gastropoda & 0.50 & 2.67 & 0.90 & 9.12 & 0.15 & 3.09 & 0.73 & 8.86 \\
\hline Ostracoda & 0.77 & 11.31 & 0.35 & 1.13 & 0.60 & 8.44 & 0.23 & 2.55 \\
\hline Nematoda & 0.59 & 9.79 & 0.55 & 15.53 & 0.70 & 31.72 & 0.60 & 9.55 \\
\hline Copepoda & 0.82 & 53.79 & 0.25 & 0.77 & 0.30 & 39.65 & 0.03 & 0.53 \\
\hline Cladocera & 0.32 & 0.28 & - & - & - & - & - & - \\
\hline Trichoptera & 0.09 & 0.09 & 0.20 & 0.58 & 0.05 & 0.06 & 0.30 & 0.28 \\
\hline Ephemeroptera & - & - & 0.05 & 0.03 & 0.10 & 0.45 & 0.10 & 0.29 \\
\hline Hydracarina & 0.23 & 1.59 & 0.20 & 0.21 & 0.05 & 0.06 & 0.20 & 0.14 \\
\hline Coleoptera & - & - & 0.05 & 0.06 & 0.15 & 0.19 & 0.07 & 0.14 \\
\hline Odonata & - & - & 0.05 & 0.06 & - & - & - & - \\
\hline Collembola & - & - & - & - & - & - & 0.04 & 0.01 \\
\hline Other & 0.18 & 0.67 & 0.20 & 0.46 & 0.15 & 0.25 & - & - \\
\hline Arthropoda remains & 0.18 & - & 0.30 & - & - & - & - & - \\
\hline Vegetal remains & 0.41 & - & 0.30 & - & - & - & 0.23 & - \\
\hline Sediment/debris & 0.72 & - & 0.80 & - & 0.40 & - & 0.60 & - \\
\hline
\end{tabular}

May showed Diptera as the dominant item following by Bivalvia. Gastropoda and Nematoda were frequently consumed with higher values than those observed in individuals of size class 1 (Fig. 2b). The diagram of November revealed that Diptera were the dominant item while Gastropoda, Nematoda and Bivalvia were frequent items with lower $\mathrm{P}_{\mathrm{i}}$ (Fig. 2d).

\section{Diet variations between size classes}

The CA was resolved only with one dimension, which explained $100 \%$ of the inertia and highlights the existence of a single main gradient in I. labrosus diet. The feeding pattern was significantly different between size classes (total $\chi^{2}$ : $9614.0, \mathrm{df}=7, P<0.0001)$. Size class 1 fishes were associated to Copepoda, Cladocera, and Ostracoda, whereas fishes of size class 2 were associated to Diptera larvae (mainly Chironomidae), Gastropoda, and Trichoptera. Two food groups, Bivalvia, and Nematoda, did not show a strong relationship with size classes (Fig. 3).

\section{Temporal diet variations}

The CA for fishes of each size class was resolved with one dimension, which explained $100 \%$ of the inertia. The feeding pattern was significantly different between the studied months (total $\chi^{2}: 406.31, \mathrm{df}=5, P<0.0001$ and total $\chi^{2}: 2425.42, \mathrm{df}=4, P<$ 0.0001 , for size classes 1 and 2 respectively). In size class 1 , Bivalvia, Ostracoda, and Copepoda were items associated to May while Nematoda, Gastropoda and Diptera were associated to November (Fig.4a). For size class 2, Gastropoda, Diptera, and Ostracoda were associated to May, whereas Nematoda, and Bivalvia were associated to November (Fig. 4b).

\section{Morphometric relationships}

Some of the morphometric relationships explored showed significantly different $(P<0.05)$ allometric coefficient values (b) compared with the $b$ values assuming isometric growth ( $b=1$ or $b=3$, for length-length and length-weight relationships after $\log _{10}-\log _{10}$ transformation, respectively). The intestine length decreased significantly as standard length increased $(b=0.81, P<0.05)$. Eye diameter and mouth width showed negative allometric growth in relation to head length growth ( $b=0.67, P<0.05 ; b=0.84, P<0.05$, respectively). Finally, head length and body weight showed an isometric trend with the standard length $(b=1.00, P>0.05$; and $b=3.01, P>0.05$ respectively) (Table 4 ).

\section{Discussion}

\section{Diet}

Iheringichthys labrosus is a common species in Uruguay River, being the most abundant in the studied period. The species showed a broad feeding spectrum, with most components belonging to benthic community. This fact indicates that I. labrosus is a benthophagous species in Uruguay River in agreement with the diet described before for lotic (Fugi et al., 2001; Abes et al., 2001; Fagundes et al., 2008) and lentic Brazilian systems (Peretti \& Andrian, 2004).

An interesting point to highlight is that the main prey items belonging to the Bivalvia group are invasive species: Corbicula sp. and Limnoperna fortunei (Brugnoli et al., 2006). Those species can cause habitat degradation affecting biodiversity and functioning of ecosystems, and are able to promote subsequent invasions and economic and social 


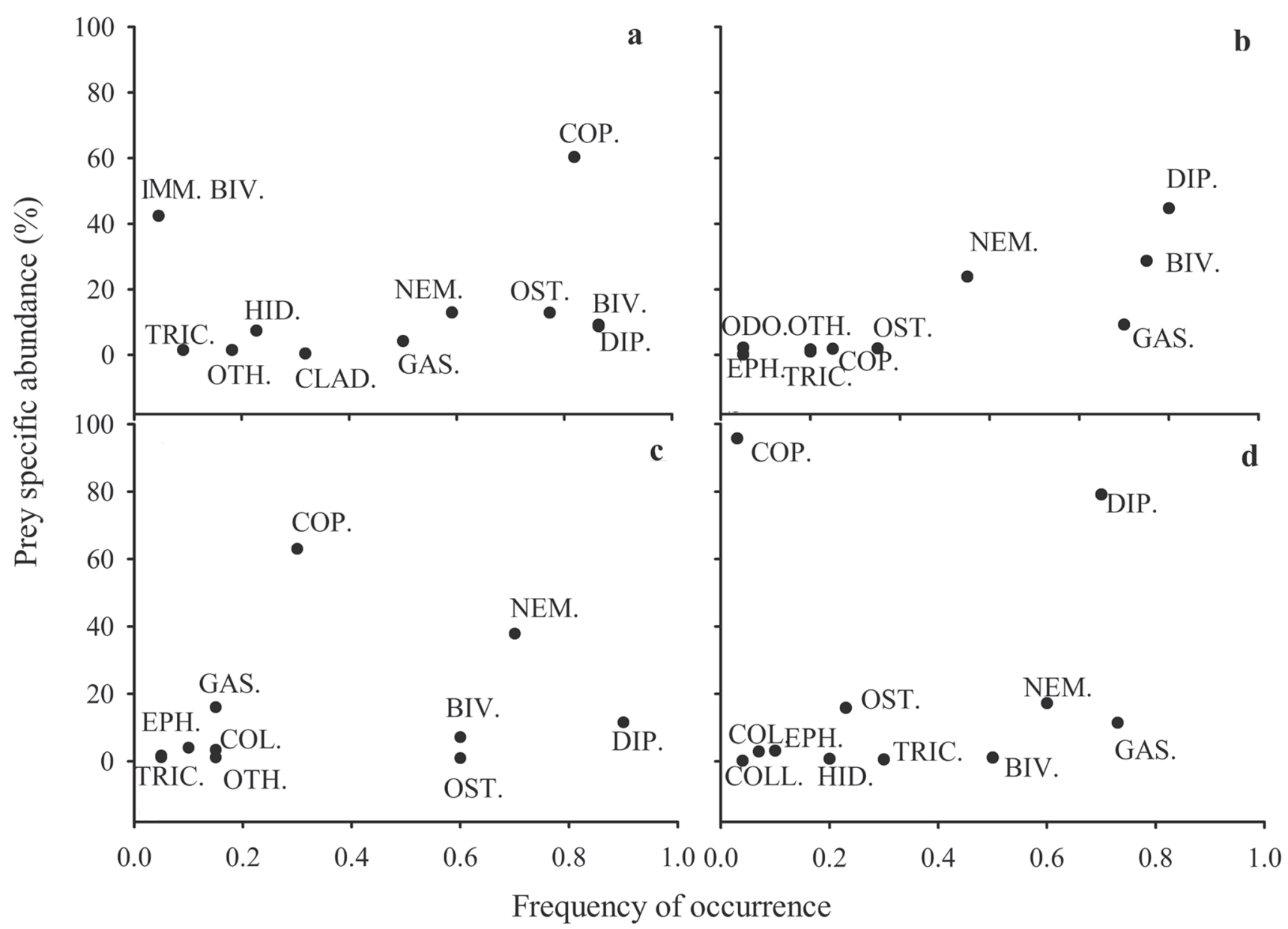

Fig. 2. Amundsen diagrams for individuals of the size class $1(\mathrm{a}-\mathrm{c})$ and 2 (b-d). Superior diagrams correspond to individual obtained in May and inferior to individual obtained in November. COP: Copepoda, TRIC: Trichoptera, OTH: others, HYD: Hydracharina, CLAD: Cladocera, GAS: Gastropoda, NEM: Nematoda, OST: Ostracoda, BIV: Bivalvia, DIP: Diptera, EPH: Ephemeroptera, IMM. BIV: immature bivalvia, ODO: Odonata, COL: Coleoptera, COLL: Collembola.

impacts (D'Antonio et al., 2001). Particularly, L. fortunei is responsible for changes in the benthic community of La Plata River (Darrigran et al., 1998). Moreover, this species is able to cause "macrofouling" (e.g. filter obstructions, refrigerated systems damage, tubes diameter diminution) affecting human activities and causing economic loses (Mansur et al., 2003). Trough predation, I. labrosus may represent a natural and abundant predator of these two harmful species of freshwater ecosystems, and could play an important role in terms of controlling dispersion ranges of these Bivalvia species. One the other hand, I. labrosus may act as disperser in case bivalves survive to the digestion (Cantanhêde et al., 2008). In this study, however, most of these bivalves were found broken and totally digested.

\section{Diet variations between size classes}

Feeding ontogenetic changes on fish populations reduce potential intraspecific diet competition (Lima-Junior \& Goiten, 2003). Despite that I. labrosus does not exhibit changes in feeding strategy between sizes, there was qualitative and quantitative diet changes associated to growth. The main difference is given for microcrustaceans preference (Copepoda, Cladocera, Ostracoda) by fishes belonging to size class 1 and this fact has been frequently reported (e.g. García-Berthou \& Moreno-Amich, 2000; Hjelm et al., 2000; Canto-Maza \& Vega-Cendejas, 2007). This seems to be related to the high availability and easy access of those preys for small juvenile fishes with scarce mobility (Cassemiro et al., 2008). In other way, juvenile fishes must maximize the growth and survival because of their vulnerability in early stages of life (Pilatti \& Vanni, 2007). In that sense, Microcrustaceans are abundant preys, which may constitute an important protein and queratine source (Canto-Maza \& Vega-Cendejas, 2007).

Bivalvia, Diptera larvae, Gastropoda, and Nematoda were important preys of all size fishes, however, they were more associated to size class 2. Probably, this reflects the greater success of larger fishes to catch those preys. It is well known 


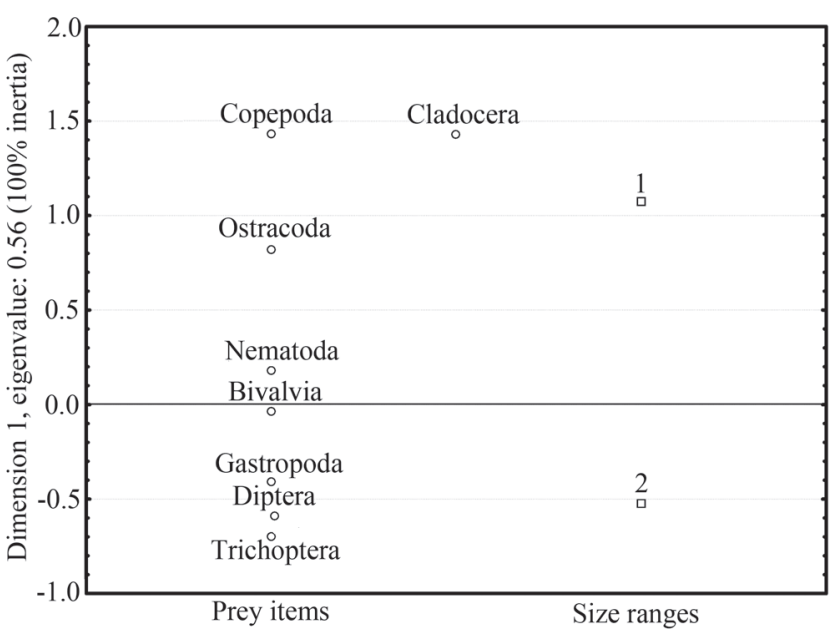

Fig. 3. Correspondence analysis between prey items (circles) and fish size ranges (squares), 1 and 2. Note that the analysis resolved in only one dimension.

that capture efficiency increases through ontogeny in response to nutritional demand increment (Adriaens et al., 2001).

\section{Temporal diet variations}

The tendency of diet variation was different in both size classes. This fact may indicate temporal diet segregation between size classes, which may be related to seasonal differences in energetic requirements. In addition, differences between months can be related to changes in prey availability (Stoner, 1980) or in feeding behaviour, due to changes in physiological requirements related for example to temperature (Magnan et al., 1994), being difficult to determine the main cause of variation.

\section{Morphometric relationships}

Iheringichthys labrosus intestine length shows negative allometry trough development. Relative intestine length reflects diet quality (Al-Hussaini, 1947; Horn, 1989). In this context, allometric intestine growth could be associated to qualitative diet changes trough fish development (e.g. Teixeira-de Mello et al., 2006). However, we did not find diet changes between size classes which may explain the negative allometry found for intestine growth. Nevertheless, a possible explanation could be related to energetic constrains associated to body size, because larger individuals have higher energetic demands (Mc Nab, 2002) and the maintenance of large structures as the intestine, implies elevated and, in this case, probably unnecessary energetic costs.

The eye diameter development showed negative allometric growth, indicating that smaller individuals have proportionally larger eyes. Assuming that larger eyes imply a better vision, one possible explanation is that juvenile fishes need enhanced vision to detect little preys like microcrustaceans. At the same time, an improved vision could be useful to perceive predators in this fragile stage of life.
However, considering eye diameter, negative allometric growth seems to be a very common characteristic for most fish species, independently if they are typically visual predators or not (Piet, 1998). This kind of growth seems to emerge from different selective pressures independent of visual abilities (Lima-Junior \& Goiten, 2003). In addition, the eye size of Siluriformes probably does not play an important role in feeding search, because they have alternative sensorial mechanisms like whiskers or gills for searching resources (Fink \& Fink, 1979; Gregory, 1993).

Mouth width shows a negative growth that indicates a relative size reduction trough ontogeny. However, the increment in absolute size of mouth's predator is one of the main causes for prey size variations (Piet, 1998). This may determine the type of prey that fishes can access according to their body size. This fact could explain, at least partially, the qualitative differences found between fish size classes.

Finally, this species showed an isometric trend between head length and body weight in relation to standard length, which indicates a proportional increment of those variables with the increment in length. The weight-length relationship

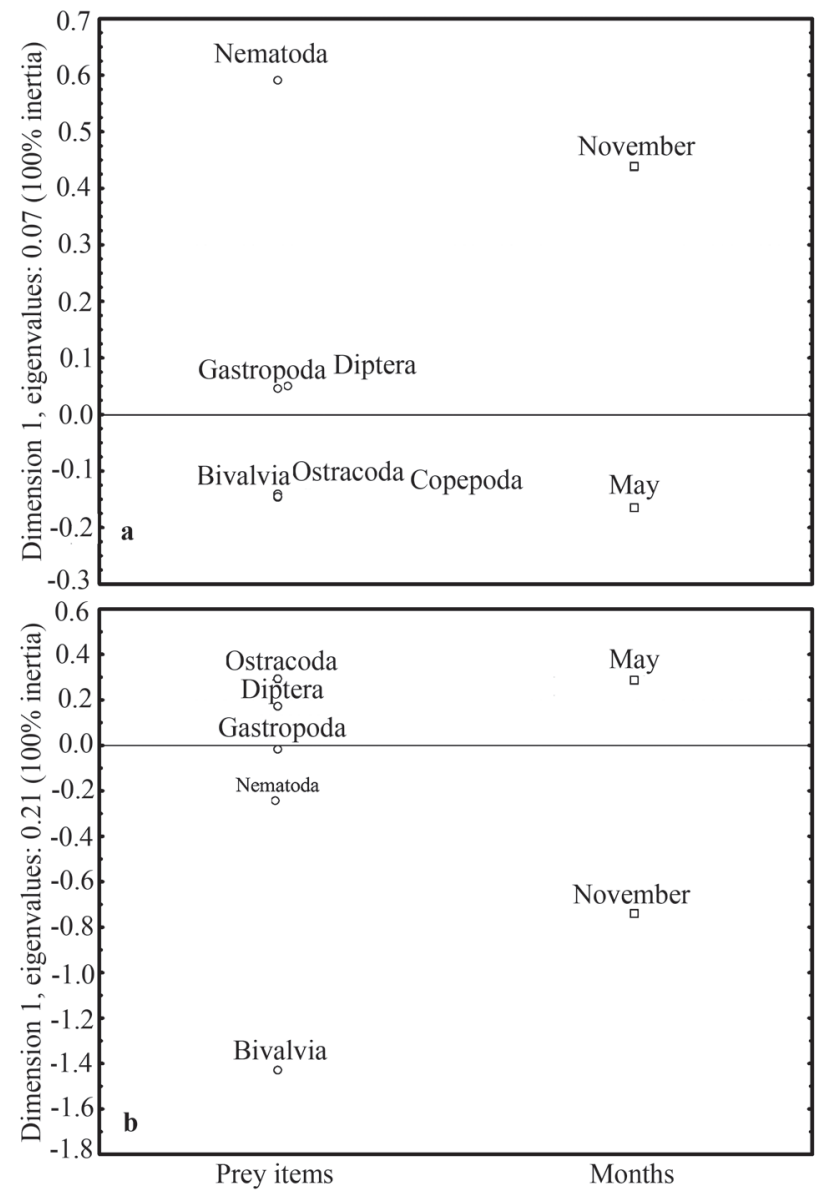

Fig. 4. Correspondence analysis between prey items (circles) and studied months (squares). (a) Prey items of individuals of the size class 1 (b) Prey items of individuals of the size class 2 . Note that the analysis resolved in only one dimension. 
Table 4. Morphometric traits measured for Iheringichthys labrosus. $\mathrm{n}=$ number of individuals considered for measures, $\max =$ maximum, min $=$ minimum, $a=$ intercept of relationship, $b=$ slope of relationship, S.E. $=$ standard error, $r^{2}=$ coefficient of determination. *significantly different $(t$-test; $P<0.05)$ allometric coefficient values $(b)$ compared with the $b$ values assuming

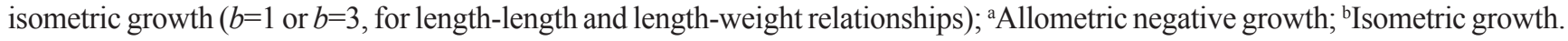

\begin{tabular}{|c|c|c|c|c|c|c|c|}
\hline \multirow[b]{2}{*}{ Morphometric variables } & \multicolumn{6}{|c|}{ Parameters of the relationship } & \multirow[b]{2}{*}{$r^{2}$} \\
\hline & $\mathrm{n}$ & Mean \pm S.E. & Min. & Max. & $\alpha \pm$ S.E. & $b \pm$ S.E. & \\
\hline S. length & 103 & $123.6 \pm 4.6$ & 62.0 & 224.0 & - & - & - \\
\hline I. length & 90 & $170.9 \pm 8.2$ & 45.0 & 310.0 & $1.96( \pm 0.05)$ & $0.81 *( \pm 0.02)$ & $0.92^{\mathrm{a}}$ \\
\hline B. weight & 103 & $67.2 \pm 4.4$ & 26.6 & 174.0 & $0.02( \pm 0.07)$ & $3.01( \pm 0.06)$ & $0.99^{\mathrm{b}}$ \\
\hline H. length & 31 & $35.3 \pm 2.5$ & 16.0 & 62.0 & $0.30( \pm 0.1)$ & $1.00( \pm 0.05)$ & $0.93^{\mathrm{b}}$ \\
\hline E. diameter & 31 & $7.8 \pm 0.4$ & 4.0 & 12.0 & $0.71( \pm 0.07)$ & $0.67 *( \pm 0.04)$ & $0.90^{\mathrm{a}}$ \\
\hline M. width & 27 & $6.3 \pm 0.4$ & 3.0 & 10.0 & $0.32( \pm 0.14)$ & $0.84 *( \pm 0.09)$ & $0.91^{\mathrm{a}}$ \\
\hline
\end{tabular}

differed from that reported previously by Teixeira-de Mello et al. (2008) in Uruguay River, and from Holzbach et al. (2009) in Piquiri River. Both studies indicated a positive allometric growth for this species. These differences highlight the dependence of weight-length relationship with local conditions and seasonality, and eventually to the existence of local morphs associated to them.

This is the first work that studies Iheringichthys labrosus diet and morphometry in the lower Uruguay River. Our results support that I. labrosus feeds on a wide spectrum of benthic organisms. The generalist diet of this fish confers high resistance to potential resource changes, and may explain the high abundance of I. labrosus in the Uruguay River basin. This species shows quantitative and qualitative diet variations between size classes. This may reflect different energetic demands, biological priorities and different abilities to capture preys trough fish development. However, we did not find a clear connection between diet shifts and morphometric changes. Therefore, in this particular case, the allometric growth of certain structures related to feeding does not seem to be related to diet variations, suggesting that other external or internal pressures may operate on morphometric variables.

\section{Acknowledgements}

For their invaluable collaboration we wish to thank to: Diego Larrea, Juka Tanna, Iván Gonzalez-Bergonzoni, Carlos Iglesias and Roberto Ballabio for the data collection, Juan Clemente for the assessing in the taxonomic classification of benthic prey items, Luciana Mello de Carvalho for the Portuguese translation, Luis Aubriot for assistance in the graphical layout and for English improvement, and Gervasio González of UPM S.A. for providing vital information for this report. We are grateful to anonymous reviewers and to the Editor Norma Segatti Hahn for the valuable contributions. Teixeira-de Mello F., M. Arim and M. Loureiro are supported by SNI (Sistema Nacional de Investigación, ANII, Uruguay).

\section{Literature Cited}

Abes, S. S., A. A. Agostinho, E. K. Okada \& L. C. Gomes. 2001. Diet of Iheringichthys labrosus (Pimelodidae, Siluriformes) in the Itaipu Reservoir, Paraná River, Brazil-Paraguay. Brazilian Archives of Biology and Technology, 44: 101-105.

Adriaens, D., P. Aerts \& W. Verraes. 2001. Ontogenetic shift in mouth opening mechanisms in a catfish (Clariidae, Siluriformes): A response to increasing functional demands. Journal of Morphology, 247:197-216.

Al-Hussaini, A. H. 1947. The feeding habits and the morphology of the alimentary tract of some teleosts living in the neighbourhood of the Marine Biological Station, Ghardaga, Red Sea. Publications of the Marine Biology Station, Ghardaga, Red Sea, 5: 1-61.

Amundsen, P. A., H. M. Gabler \& F. J. Staldvik. 1996. A new approach to graphical analysis of feeding strategy from stomach contents data-modification of the Costello (1990) method. Journal of Fish Biology, 48: 607-614.

Arim, M., S. Abades, G. Laufer, M. Loureiro \& P.A. Marquet. 2010. Food web structure and body size: trophic position and resource acquisition. Oikos, 119: 147-153.

Arim, M. \& D. E. Naya. 2003. Pinniped diets inferred from scats: analysis of biases in prey occurrence. Canadian Journal of Zoology, 81: 67-73.

Bertoletti, J. J., C. A. S. Lucena, Z. M. S., Lucena, L. R. Malabarba \& R. E. Reis. 1989. Ictiofauna do rio Uruguai superior entre os municípios de Aratiba e Esmeralda, Rio Grande do Sul, Brasil. Comunicações do Museu de Ciências da PUCRS 48: 3-42.

Brugnoli, E., J. Clemente, G. Riestra, L. Boccardi \& A. Borthagaray. 2006. Especies acuáticas exóticas en Uruguay: situación, problemática y gestión. Pp. 351-361. In: Menafra, R., L. RodríguezGallego, F. Scarabino \& D. Conde (Eds.). Uruguay: Bases para la conservación y manejo de la costa uruguaya. Vida Silvestre Uruguay, Montevideo, 668p.

Burges, W. E. 1989. An atlas of freshwater and marine catfishes: a preliminary survey of the Siluriformes. New Jersey, T. F. H. Publications, 784p.

Cantanhêde, G., N. S. Hahn, E. A. Gubiani, R. Fugi. 2008. Invasive molluscs in the diet of Pterodoras granulosus (Valenciennes, 1821) (Pisces, Doradidae) in the Upper Paraná River floodplain, Brazil. Ecology of Freshwater Fish, 17: 47-53.

Canto-Maza, W. G. \& M. E. Vega-Cendejas. 2007. Distribución, abundancia y preferencias alimenticias del pez sapo Opsanus phobetron (Batrachoididae) en la laguna costera de Chelem, Yucatán, México. Revista de Biología Tropical, 55: 979-988.

Cassemiro, F. A. S., T. F. L. V. B. Rangel, F. M. Pelicice \& N. S. Hahn. 2008. Allometric and ontogenetic patterns related to feeding of a neotropical fish, Satanoperca pappaterra (Perciformes, Cichlidae). Ecology of Freshwater Fish, 17: 155-164.

D’Antonio, C., L. A. Meyerson \& J. Denslow. 2001. Exotic species and conservation. Pp. 59-80. In: Soulé, M. E. \& G. H. Orians 
(Eds.). Conservation Biology: Research Priorities for the Next Decade. Island, Washington, DC, 307p.

Darrigran, G., M. Martín, B. Gullo \& L. Armendáriz. 1998. Macroinvertebrates associated with Limnoperna fortunei (Dunker, 1857) (Bivalvia, Mytilidae) in Río de la Plata, Argentina. Hydrobiology, 367: 223-230.

Deus, C. P. \& M. Petrere-Junior. 2003. Seasonal diet shifts of seven fish species in an Atlantic rainforest stream in southeastern Brazil. Brazilian Journal Biology, 63: 579-588.

Dill, L. M. 1983. Adaptive flexibility in the foraging behaviour of fishes. Canadian Journal of Fisheries and Aquatic Sciences, 40: 398-408.

DINAMA. 2005. Instalación de plantas de celulosa y obras accesorias. Cap. 3 Descripción del medio. Exp. 2004/14001/1/01177.

Fagundes, C. K., E. R. Behr \& C. B. Kotzian. 2008. Diet of Iheringichthys labrosus (Siluriformes, Pimelodidae) in the Ibicuí River, Southern Brazil. Iheringia, Série Zoologia, 98: 60-65.

Fink, W. L. \& S. V. Fink. 1979. Central Amazonia and its fish. Comparative Biochemistry and Physiology. Part A: Molecular \& Integrative Physiology, 62: 13-29.

Fugi, R., A. A. Agostinho \& N. S. Hahn. 2001. Trophic morphology of five benthic-feeding fish species of a tropical floodplain. Revista Brasileira de Biología, 61: 27-33.

García-Berthou, E. \& R. Moreno-Amich. 2000. Food of introduced pumpkinseed sunfish: ontogenetic diet shift and seasonal variation. Journal of Fish Biology, 57: 29-40.

Gregory, R. S. 1993. Effect of turbidity on the predator avoidance behaviour of juvenile Chinook salmon (Oncorhynchus tshawytscha). Canadian Journal of Fisheries and Aquatic Sciences, 50: 241-246.

Hjelm, J., L. Persson \& B. Christensen. 2000. Growth, morphological variation and ontogenetic niche shifts in perch (Perca fluviatilis) in relation to resource availability. Oecologia, 122: 190-199.

Holzbach, A. J., E. A. Gubiani \& G. Baumgartner. 2009. Iheringichthys labrosus (Siluriformes: Pimelodidae) in the Piquiri River, Paraná, Brazil: population structure and some aspects of its reproductive biology. Neotropical Ichthyology, 7: 55-64.

Horn, M. H. 1989. Biology of marine herbivorous fishes. Oceanography and Marine Biology Annual Review 27, 167-272.

Hyslop, E. J. 1980. Stomach contents analysis a review of methods and their application. Journal of Fish Biology, 17: 411-429.

Kramer, D. L. \& M. J. Bryant. 1995a. Intestine length in the fishes of a tropical stream: 1. Ontogenetic allometry. Environmental Biology Fisheries, 42: 115-127.

Kramer, D. L. \& M. J. Bryant. 1995b. Intestine length in the fishes of a tropical stream: 2. Relationships to diet: the long and short of a convoluted issue. Environmental Biology of Fishes, 42, 129-141.

Lima-Junior, S. E. \& R. Goitein. 2003. Ontogenetic diet shifts of a Neotropical catfish, Pimelodus maculatus (Siluriformes, Pimelodidae): An ecomorphological approach. Environmental Biology of Fishes, 68: 73-79.

Lowe, C. G., B. M. Wetherbee, G. L. Crow \& A. L. Tester. 1996. Ontogenetic dietary shifts and feeding behavior of the tiger shark, Galeocerdo cuvieri, in Hawaiian waters. Environmental Biology Fisheries, 47: 203-211.

Magnan, P., M. A. Rodríguez, P. Legendre \& S. Lacasse. 1994. Dietary variation in a freshwater fish species: relative contribution of biotic interactions, abiotic factors, and spatial structure. Canadian Journal of Fishes Aquatic Science, 51: 2856-2865.

Mansur, M. C., C. P. Santos, G. Darrigan, I. Heydrich, C. T. Callil \& F. R. Cardoso. 2003. Primeiros dados quali-quantitativos do “mexilhão dourado", Limnoperna fortunei (Dunker, 1857), no lago Guaíba, Bacia da laguna dos Patos, Rio Grande do Sul, Brasil e alguns aspectos de sua invasão no novo ambiente. Revista Brasileira de Zoologia, 22: 75-84

Mc Nab, B. K. 2002. The physiological ecology of vertebrates. Ithaca, Cornell University Press, 576p.

Peretti, D. \& I. F. Andrian. 2004. Trophic structure of fish assemblages in five permanent lagoons of the high Paraná River floodplain, Brazil. Environmental Biology of Fishes, 71: 95-103.

Piet, G. J. 1998. Ecomorphology of a size-structured tropical freshwater fish community. Environmental Biology Fisheries, 51: 67-86.

Pilatti, A. \& M. J. Vanni. 2007. Ontogeny, diet shifts, and nutrient stoichiometry in fish. Oikos, 116: 1663-1674.

Pouilly, M., S. Barrrera \& C. Rosales. 2006. Changes of taxonomic and trophic structure of fish assemblages along an environmental gradient in the Upper Beni watershed (Bolivia). Journal of Fish Biology, 68: 137-157.

Raffaelli, D. 2007. Food web, body size and the curse of the latin binomial. Pp. 53-64. In: Rooney, N., K. S. McCann \& D. L. G. Noakes (Eds). From Energetics to Ecosystems: the dynamics and structure of ecological systems. The Netherlands, Springer, 265p.

Rowe, D. K. \& B. L. Chisnall. 1996. Ontogenetic habitat shifts by Galaxias galaxies (Galaxiidae) between the littoral and limnetic zones of Lake Kanono, New Zealand. Environmental Biology Fisheries, 46: 255-264.

Santos, J. E., G. E. V. Padilha, O. Bomcompagni-Júnior, G. B. Santos, E. Rizzo \& N. Bazzoli. 2006. Ovarian follicle growth in the catfish Iheringichthys labrosus (Pimelodidae, Siluriformes) Tissue and Cell, 38: 303-310.

Sokal, R. R. \& F. J. Rohlf. 1969. Biometría. Blume Ediciones, Madrid, 832 p.

Stoner, A. W. 1980. Feeding ecology of Lagodon rhomboides (Pisces: Sparidae): variation and functional responses. Fishery Bulletin, 78: 337-352.

Teixeira-de Mello, F., C. Iglesias, A. I. Borthagaray, N. Mazzeo, J. Vilches, D. Larrea \& R. Ballabio. 2006. Onthogenic allometric coefficient changes. Implicances of diet shift and morphometric attributes in Hoplias malabaricus (Bloch) (Characiformes, Erythrinidae). Journal of Fish Biology, 69: 1770-1778.

Teixeira-de Mello, F., N. Vidal, I. Gonzalez-Bergonzoni \& C. Iglesias. 2008. Length-weight relationship of eight fish species from the lower section of the Uruguay River (Río Negro, Uruguay). Journal of Applied Ichthyology, 25: 128-129.

Wainwraigth, P. C. \& B. Richard. 1995. Predicting patterns of prey use from morphology of fishes. Environmental Biology of Fishes, 44: 97-113.

Ward-Campbell, B. M. S. \& F. W. H. Beamish. 2005. Ontogenetic change in morphology and diet in the snakehead, Channa limbata, a predatory fish in western Thailand. Environmental Biology of Fishes, 72: 251-257.

Wootton, R. J. 1992. Fish Ecology. New York, Chapman \& Hall. $212 \mathrm{p}$.

Submitted April 27, 2010

Resubmitted December 28, 2010

Accepted June 15, 2011

Published September 16, 2011 